\title{
Peritoneal fluid changes in horses subjected to small colon distension ${ }^{1}$
}

\author{
Rafael R. Faleiros ${ }^{2}$, Delphim G. Macoris ${ }^{3}$, Carlos Henrique C. Saquetti ${ }^{4}$, Andrea \\ C. Aita ${ }^{5}$, Anderson Farias ${ }^{6}$, Euclides B. Malheiros ${ }^{7}$ and Ivan B.M. Sampaio ${ }^{8}$
}

\begin{abstract}
Faleiros R.R., Macoris D.G., Saquetti C.H.C., Aita A.C., Farias A., Malheiros E.B. \& Sampaio I.B.M. 2011. Peritoneal fluid changes in horses subjected to small colon distension. Pesquisa Veterinária Brasileira 31(5):367-373. Departamento de Clínica e Cirurgia Veterinárias, Escola de Veterinária, Universidade Federal de Minas Gerais, Belo Horizonte, MG 31270-901, Brazil. E-mail: faleiros@ufmg.br

Intestinal devitalization in cases of small colon obstruction may be difficult to detect based only in clinical signs. The purpose was to serially evaluate blood and peritoneal fluid of horses subjected to small colon distension. Seventeen adult horses were allotted in three groups. In the small colon-distended group (DG, $n=7)$ a surgically-implanted latex balloon was inflated to promote intraluminal small colon distension. In the shamoperated group ( $S G, n=5)$, the balloon was implanted but not inflated, and no surgery was done in the control group ( $C G, n=5)$. Blood and peritoneal fluid were sampled before and after (6 samples with a 30-minute interval) intestinal obstruction for cytological and biochemical analyses. No significant changes in clinical signs occurred within groups or across time during the experimental period. There were no statistical differences among SG and SG groups in hematologic and blood chemistry variables. Although total protein concentration and lactate dehydrogenase (LDH) activity in peritoneal fluid remained most of the time within reference values during the experimental period in all groups, increases from baseline values were detected in SG and DG groups. Such increases occurred earlier, progressively and with greater magnitude in the DG when compared with the $S G(P<0.05)$. Increases from baselines values were also observed in total nucleated cells and neutrophils counts in the DG $(P<0.05)$. In conclusion, distension of the equine small colon induced progressive subtle increases in total protein and LDH concentrations in the peritoneal fluid during the first hours. Serial evaluation of these variables in peritoneal fluid may be useful for early detection of intestinal devitalization in clinical cases of equine small colon obstruction.
\end{abstract}

INDEX TERMS: Peritoneal fluid, small colon, horse.

${ }^{1}$ Received on June 25, 2010.

Accepted for publication on October 17, 2010.

Part of the first author's Dr. thesis.

2 Departamento de Clínica e Cirurgia Veterinárias, Escola de Veterinária, Universidade Federal de Minas Gerais (UFMG), Avenida Antônio Carlos 6627, Pampulha, Belo Horizonte, MG 31270-901, Brazil. *Corresponding author: faleiros@ufmg.br

3 Programa de Pós-Graduação em Cirurgia Veterinária, Departamento de Medicina e Cirurgia Veterinária, Departamento de Clínica e Cirurgia Veterinária, Universidade Estadual Paulista (Unesp), Via de Acesso Paulo Donato Castelane s/n, Jaboticabal, SP 14870-000, Brazil.

${ }^{4}$ Departamento de Estatística, Unesp, Jaboticabal, SP 14870-000.

5 Departamento de Zootecnia, Escola de Veterinária, UFMG, Belo Horizonte, MG 31270-901.
RESUMO.- [Alterações no líquido peritoneal de equinos submetidos a distensão do cólon menor.] $A$ desvitalização do cólon menor em equinos pode ser difícil de ser detectada baseando-se apenas em sinais clínicos. O objetivo foi realizar uma avaliação seriada do líquido peritoneal de equinos submetidos à distensão do cólon menor. Dezessete cavalos adultos foram divididos aleatoriamente em três grupos. No grupo distendido (DG, $n=7$ ) um balão implantado cirurgicamente foi inflado para promover distensão do cólon menor. No grupo instrumentado (SG, $n=5$ ) o balão foi implantado, mas sem promover distensão e no grupo controle (CG, $n=5$ ) não houve anestesia ou cirurgia. Sangue e fluido peritoneal foram colhidos 
antes e durante 180 minutos após a cirurgia para análises citológicas e bioquímicas. Nenhuma interação significativa ocorreu entre grupos e tempos nas variáveis clínicas e hematológicas. Apesar dos valores de proteínas totais e da atividade da lactato desidrogenase (LDH) permanecerem dentro da normalidade durante quase todo o experimento, aumentos em relação aos valores basais ocorreram nos grupos SG e DG. Contudo, tais aumentos foram precoces, progressivos e em maior magnitude em DG quando comparados ao SG, mostrando que a distensão promoveu alterações significativas nessas variáveis $(P<0.05)$. Aumentos em relação aos valores basais também ocorreram nas contagens de células totais nucleadas e neutrófilos $(P<0.05)$. Em conclusão, a distensão experimental do cólon menor promove, nas primeiras horas, alterações subliminares progressivas nas concentrações de proteínas totais e na atividade de LDH no líquido peritoneal. Os resultados indicam que a avaliação seriada do liquido peritoneal pode ser útil para detectar desvitalização intestinal em casos clínicos de obstrução do cólon menor equino.

TERMOS DE INDEXAÇÃO: Líquido peritoneal, cólon menor, equino.

\section{INTRODUCTION}

Although the overall incidence of diseases affecting the equine small colon has been considered low (Snyder \& Spiers 1996, Edwards 1997), luminal obstruction of this segment by enteroliths and foreign material has been reported as an important cause of abdominal surgery in specific geographic regions (Hassel et al. 1999) and in large Brazilian cities (Faleiros et al. 2001, Correa et al. 2006).

Horses affected by simple obstruction of the small colon are reported to do not show clinical signs of acute abdominal disease as overtly as horses with diseases in other segments of the gastrointestinal tract (Datt \& Usenik 1975, Blue 1979, Gay et al. 1979, Dart et al. 1992, Hassel et al. 1999, Rhoads et al. 1999). In addition, blood and peritoneal fluid variables routinely analysed are generally within the normal range values in most of the reported cases of obstructions by ingesta impaction (Rhoads et al. 1999), enteroliths (Hassel et al. 1999), and foreign bodies (Gay et al. 1979).

The slow deterioration of the cardiovascular status, the lack of manifestation of severe pain, and the absence of significant changes in laboratory values usually delays medical care to the patient and can compromise the decision-making process about surgical procedures. Therefore, intestinal devitalisation may occur, eventually leading to intestinal perforation and contamination of the peritoneal cavity, which usually leads to euthanasia in most cases (Gay et al. 1979, Hassel et al. 1999). From more than one thousand horses affected by enteroliths during a thirty-year period, approximately one-third were euthanatized due to intestinal rupture $(15.1 \%)$, unfavourable prognosis or financial constraints (Hassel 2002). From the cases of intestinal rupture, the majority $(71 \%)$ occurred in the small colon (Hassel et al. 1999).

The objective of this study was to evaluate peritoneal fluid changes in horses subjected to experimental luminal obstruction of the small colon. The hypothesis was that serial evaluation of peritoneal fluid in such horses can reveal subtle progressive changes in routinely used laboratory tests.

\section{MATERIALS AND METHODS}

Animals. The experimental protocol was approved by the Committee of Ethics and Animal Welfare of the Faculdade de Ciências Agrárias e Veterinárias (no. 005690), and was performed under international guidelines for care and use of laboratory animals. Seventeen clinically normal mixed breed horses were used, five geldings and twelve non-pregnant mares, that had a mean $( \pm S D)$ age and weight of $6.5 \pm 3$ years and $330 \pm 38$ $\mathrm{kg}$ (body score of 2.5 to 3.5/5), respectively (Speirs 1997). The horses were treated with ivermectin $(200 \mu \mathrm{g} / \mathrm{kg}, \mathrm{PO})$ and were kept in small paddocks $\left(22.2^{\circ} \mathrm{C}\right.$ of mean annual temperature and $70.8 \%$ of mean annual relative humidity) for 15 days where they were supplemented with a standard diet of hay and commercial equine feed.

Horses were randomly allotted in three groups: seven with mural ischemia induced by luminal distension (distended group), five sham-operated (sham group) and five control horses (control group). In the distended group, the small colon was distended with a surgically inserted latex balloon. In the sham-operated group, the balloon was implanted but without distension, and there was no surgery or anaesthesia in the control group.

Instrumentation. After twelve hours of withholding feed but not water, horses were restrained in stocks, sedated with xylazine $(0.5 \mathrm{mg} / \mathrm{kg}, \mathrm{IV})$ and butorphanol $(0.1 \mathrm{mg} / \mathrm{kg}, \mathrm{IM})$. In horses of the distended and sham groups, local anaesthesia of the left flank was achieved by using an inverted "L" technique with combination $(1: 1)$ of $2 \%$ lidocaine and $0.5 \%$ bupivacaine. Through left flank laparotomy, the oral one-third of the small colon was exposed and exteriorized. A $5 \mathrm{~cm}$ long enterotomy was performed along the antimesenteric surface approximately $50 \mathrm{~cm}$ from the transition of the transverse colon and immediately after the intestinal segment supplied by the first radial branch of the mesenteric artery. A $15 \mathrm{~cm}$ diameter latex balloon with an extension tube attached to an inflating pump was inserted orad to the incision. To avoid displacement of the balloon in either an oral or aboral direction, the small colon on either side was loosely clamped with circumferential Penrose tubing applied in a manner to avoid occluding mesenteric and mural perfusion. The tubing was fixed on the antimesenteric border by a simple seromuscular suture using 0.60 monofilament nylon. All enterotomies were performed beyond the site where the Penrose tubing was located and they were closed with a simple continuous suture pattern using 2-0 polyglactin 910 , and allowing the extension tube to exit at the edge of the wound, and the small colon was repositioned in the peritoneal cavity. In the distended group, the balloon was inflated until a pressure of $40 \mathrm{~mm} \mathrm{Hg}$ was reached. This model had been previously proved to decrease mural perfusion to a level that corresponds to $26.4 \%$ of the mean perfusion of intact segments (Faleiros et al. 2002). In the sham-operated group, the balloon was filled with air, but causing neither positive pressure inside the balloon or distension of the intestinal lumen. In both groups, the abdominal wall was closed using a simple continuous suture pattern of polyamide $(0.60 \mathrm{~mm})$, also letting the extension tube exit at the edge of the incision.

The pressure inside the balloon was recorded by a 
previously calibrated polygraph ${ }^{6}$ connected to the extension tube by a pressure transducer ${ }^{7}$. In the distended group, the luminal pressure was checked during the first 10 minutes and every 30 minutes thereafter, and air was insufflated or removed from the balloon when it was necessary to maintain pressure as close as possible to $40 \mathrm{~mm} \mathrm{Hg}$.

Clinical and laboratorial evaluation. Cardiac and respiratory rates, capillary refill time and possible signs of intestinal pain were recorded before sedation and at 30,60, 90, 120150 and 180 minutes after balloon placement. At each of these times, blood and peritoneal fluid samples were collected.

The peritoneal fluid was evaluated for erythrocytes, and total and differential nucleated cells counts, TP, fibrinogen, and glucose concentrations, and lactate dehydrogenase (LDH) activity. The baseline samples of the peritoneal fluid were collected on unsedated horses with a needle, aseptically introduced at the most ventral position on abdominal midline. The subsequent samplings were done on sedated horses with an auto-static 60-mm-long coiled teat cannula ${ }^{8}$, introduced aseptically (Speirs 1997) in the same place where it was kept for the duration of the study.

Total nucleated cells were enumerated using an electronic cell counter ${ }^{9}$ smears were stained (May-Grünwald-Giemsa) for differential cells counts. For biochemical and enzymatic analyses, peritoneal fluid samples were separated by centrifugation $(1,500$ $x \mathrm{~g}, 10 \mathrm{~min})$ in aliquots, identified, frozen, and stored $\left(-20^{\circ} \mathrm{C}\right)$ until analysed. Fibrinogen was analysed by coagulation ${ }^{10}$, followed by reading in a coagulometer ${ }^{11}$. LDH was identified by the Pyruvate-Lactate method ${ }^{12}$, glucose by the modified Bondar and Mead method ${ }^{13}$, TP by the biuret method. All of these reactions were quantified, using a spectrophotometer ${ }^{14}$.

At the end of collection period, horses were subjected to general anaesthesia to remove the balloon. Information about this procedure is available in Faleiros et al. (2008).

Statistical analyses. The data were analysed using a splitplot experimental design with a $3 \times 7$ factorial arrangement. The treatments were the experimental units, while the repeat measures in time were the subunits. Post-hoc comparisons were made using the $t$ test to compare treatment within times and the Tukey test to compare times within treatments (Sampaio 2002). A $P<0.05$ was considered significant for all tests.

\section{RESULTS}

Surgical exteriorization and manipulation of the small colon were performed without any adverse effects that jeopardized

6 7-8P-24.5®, Grass Instruments, 600 E Greenwich Ave, West Warwick, RI, USA.

7 P 23XL@, Datex-Ohmeda Pte Ltd, 152 Beach Road, Singapore.

${ }^{8}$ Cânula Mamária Autoestática ${ }^{\circledR}$, Walmur Instr. Vet., Rua Ernesto Fontoura 231, Porto Alegre, RS.

${ }_{9}^{9}$ CC510®, Celm Companhia Equipadora de Laboratórios Modernos, Al Amazonas 764, Barueri, SP.

${ }^{10}$ Fibriquick $\AA$, Organon Teknika, 100 Rodolphe Street, Durham, NC, USA

${ }^{11}$ Coagulator $1 \circledast$, Organon Teknika, 100 Rodolphe Street, Durham, NC, USA.

12 LDH Labtest ${ }^{\circledR}$, Labtest Diagnóstica, Av. Paulo Ferreira da Costa 600, Lagoa Santa, MG.

${ }^{13}$ Glicose Labtest $\circledast$, Labtest Diagnóstica, Av. Paulo Ferreira da Costa 600, Lagoa Santa, MG.

${ }^{14}$ Labquest Bio $2000 \circledast$, Labtest Diagnóstica, Av. Paulo Ferreira da Costa 600, Lagoa Santa, MG. the procedure. No significant changes in capillary refill time and cardiac or respiratory rates occurred within groups or across time, and no horse showed signs of intense pain during the experimental period (data not shown).

No complications such as enterocentesis or spleen penetration were observed following abdominocentesis. Often during sampling, it was necessary to move the autostatic teat cannula in and out to drain the fluid, but the volumes obtained were always sufficient to perform all the tests.

In the cytological analysis of the peritoneal fluid, increases from the baseline values were observed for the total number of nucleated cells and neutrophils only in the distended group after 150 minutes of distension (Fig.1, Table 1). In the biochemical analysis of the peritoneal fluid, changes in TP concentration and LDH activity were observed. Increases from baseline values in TP and LDH means occurred in sham-operated and distended groups, but they occurred early, with a greater magnitude, and with subsequent increases in
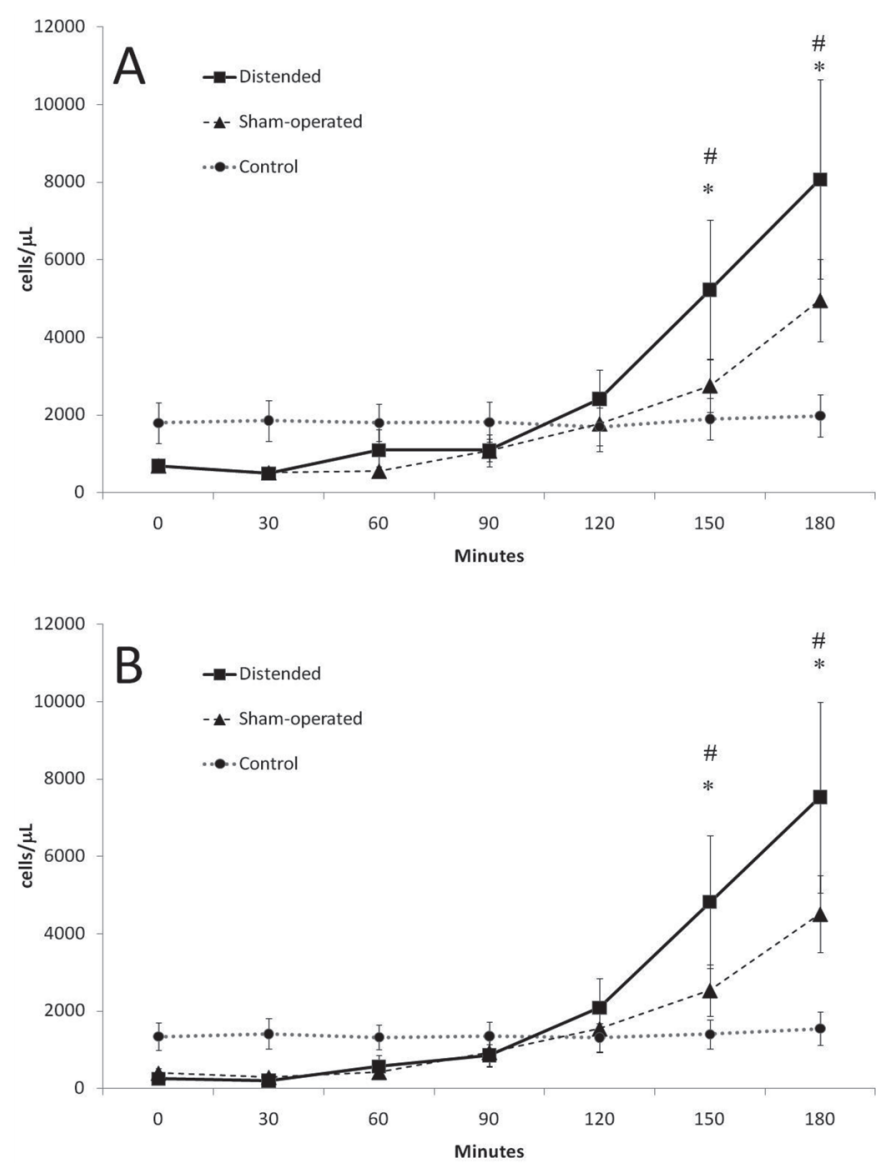

Fig.1. Mean ( \pm SEM) peritoneal fluid nucleated cell counts in horses subjected to small colon obstruction with luminal distention. Panel A: Total nucleated cells (TNC). Panel B: Segmented neutrophils. * Significant difference within a group compared with baseline values. ${ }^{* *}$ Significant difference within a group compared with the value at 90 min of distention. \# Significant difference within a time compared with the sham-operated group value $(P<0.05)$. 
Table 1. Mean (+SEM) values for erythrocyte (ERY), band neutrophil (BAN), large mononuclear cell (LMC), lymphocytes (LYM) and eosinophil (EOS) counts in peritoneal fluid from horses subjected to small colon luminal distension

\begin{tabular}{|c|c|c|c|c|c|c|c|c|}
\hline \multirow[t]{2}{*}{ Cells(/mL) } & \multicolumn{8}{|c|}{ Time (minutes) } \\
\hline & Group & Basal & 30 & 60 & 90 & 120 & 150 & 180 \\
\hline \multirow{3}{*}{ ERY } & $C G$ & $20 \pm 3$ & $22 \pm 2$ & $20 \pm 3$ & $42 \pm 16$ & $42 \pm 18$ & $36 \pm 14$ & $52 \pm 35$ \\
\hline & $S G$ & $34 \pm 18$ & $168 \pm 56$ & $116 \pm 52$ & $130 \pm 62$ & $124 \pm 52$ & $108 \pm 42$ & $116 \pm 52$ \\
\hline & $D G$ & $43 \pm 13$ & $239 \pm 145$ & $172 \pm 55$ & $169 \pm 55$ & $247 \pm 115$ & $207 \pm 85$ & $269 \pm 145$ \\
\hline \multirow{3}{*}{ BAN } & $C G$ & $0 \pm 0$ & $0 \pm 0$ & $0 \pm 0$ & $0 \pm 0$ & $0 \pm 0$ & $0 \pm 0$ & $0 \pm 0^{\mathrm{a}}$ \\
\hline & $S G$ & $2 \pm 2$ & $1 \pm 1$ & $3 \pm 1$ & $14 \pm 4$ & $6 \pm 3$ & $32 \pm 13$ & $209 \pm 62^{b}$ \\
\hline & $D G$ & $0 \pm 0$ & $1 \pm 1$ & $8 \pm 6$ & $11 \pm 3$ & $31 \pm 18$ & $91 \pm 63$ & $356 \pm 177^{c}$ \\
\hline \multirow{3}{*}{ LMC } & $C G$ & $378 \pm 172$ & $419 \pm 135$ & $388 \pm 145$ & $392 \pm 137$ & $231 \pm 98$ & $410 \pm 154$ & $345 \pm 126$ \\
\hline & $S G$ & $203 \pm 43$ & $156 \pm 37$ & $78 \pm 20$ & $87 \pm 17$ & $141 \pm 41$ & $169 \pm 46$ & $315 \pm 120$ \\
\hline & $D G$ & $354 \pm 102$ & $213 \pm 68$ & $204 \pm 247$ & $154 \pm 49$ & $237 \pm 47$ & $246 \pm 60$ & $328 \pm 52$ \\
\hline \multirow{3}{*}{ LYN } & $C G$ & $77 \pm 60$ & $63 \pm 53$ & $82 \pm 40$ & $74 \pm 50$ & $90 \pm 58$ & $81 \pm 42$ & $80 \pm 44$ \\
\hline & $S G$ & $90 \pm 22$ & $65 \pm 17$ & $54 \pm 14$ & $36 \pm 11$ & $56 \pm 32$ & $39 \pm 8$ & $106 \pm 39$ \\
\hline & $D G$ & $86 \pm 20$ & $78 \pm 15$ & $72 \pm 16$ & $70 \pm 9$ & $62 \pm 16$ & $84 \pm 22$ & $53 \pm 16$ \\
\hline \multirow{3}{*}{ EOS } & $C G$ & $0 \pm 0$ & $0 \pm 0$ & $4 \pm 4$ & $0 \pm 0$ & $1 \pm 1$ & $0 \pm 0$ & $1 \pm 1$ \\
\hline & $S G$ & $0 \pm 0$ & $1 \pm 1$ & $1 \pm 1$ & $5 \pm 5$ & $9 \pm 9$ & $0 \pm 0$ & $0 \pm 0$ \\
\hline & $D G$ & $4 \pm 3$ & $5 \pm 4$ & $5 \pm 3$ & $12 \pm 5$ & $1 \pm 2$ & $9 \pm 7$ & $23 \pm 12$ \\
\hline
\end{tabular}

$C G=$ control group, $n=5 . S G=$ sham-operated group, $n=5 . D G=$ distended group, $n=7$. Different superscript letters $(a, b, c)$ within a group across time represent significant differences. Within a given time $a^{*}$ indicates value significantly different from the control group $(P<0.05)$.

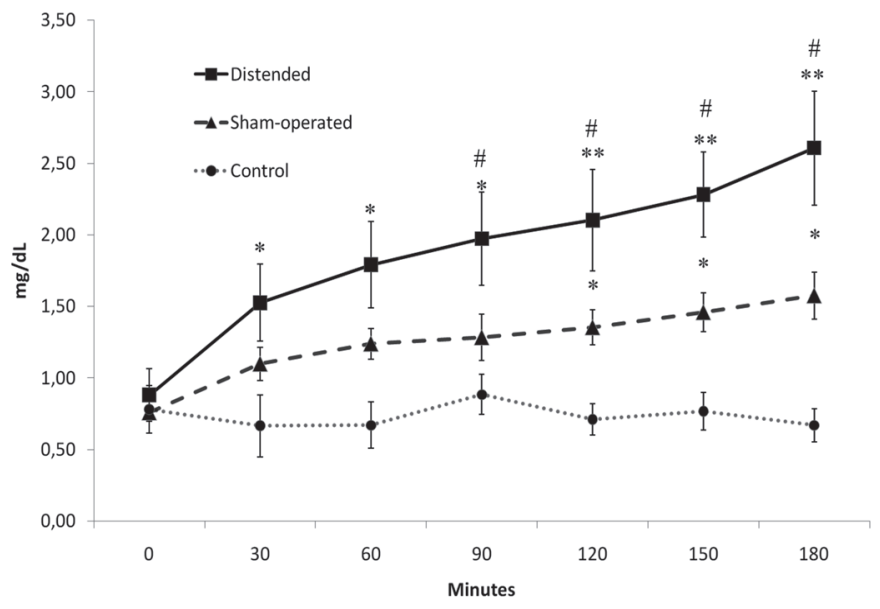

Fig.2. Mean ( \pm SEM) peritoneal fluid total protein concentration in horses subjected to small colon obstruction with luminal distension. * Significant difference within a group compared with baseline values. ${ }^{* *}$ Significant difference within a group compared with the value at $90 \mathrm{~min}$ of distension. \# Significant difference within a time compared with the shamoperated group value $(P<0.05)$.

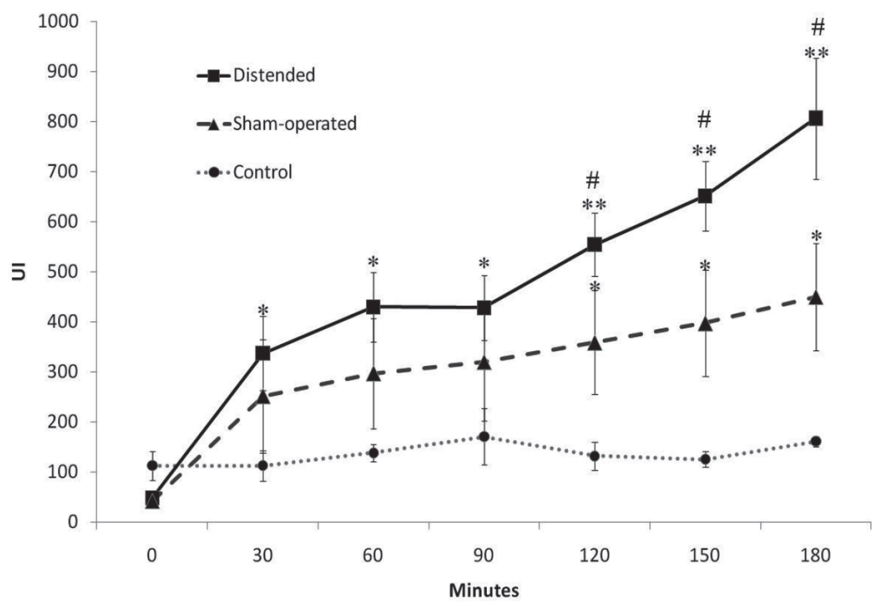

Fig.3. Mean $( \pm$ SEM) peritoneal fluid lactate dehydrogenase (LDH) activity in horses subjected to small colon obstruction with luminal distension. * Significant difference within a group compared with baseline values. ${ }^{* \star}$ Significant difference within a group compared with the value at $90 \mathrm{~min}$ of distension. \# Significant difference within a time compared with the sham-operated group value $(\mathrm{P}<0.05)$.

Table 2. Mean (+SEM) values for peritoneal fluid biochemical variables in horses subjected to small colon obstruction by experimental luminal distension

\begin{tabular}{ccccccccc}
\hline \multirow{2}{*}{ Parameter } & \multicolumn{7}{c}{ Time (minutes) } \\
\cline { 2 - 8 } & Group & Basal & 30 & 60 & 90 & 120 & 150 & 180 \\
\hline Fibrinogen & CG & $10 \pm 0.1$ & $10 \pm 0.1$ & $10 \pm 0.2$ & $10 \pm 0$ & $10 \pm 0.0$ & $10 \pm 0.0$ & $10 \pm 0.0$ \\
(mg/dL) & SG & $10 \pm 0.0$ & $10 \pm 0.0$ & $10 \pm 0.0$ & $10 \pm 0.0$ & $10 \pm 0.0$ & $10 \pm 0.0$ & $10 \pm 0.0$ \\
& DG & $13 \pm 3.3$ & $16 \pm 3.7$ & $15 \pm 3.5$ & $15 \pm 3.1$ & $15 \pm 3.2$ & $15 \pm 3.0$ & $17 \pm 3$ \\
Glucose & CG & $91 \pm 2,7$ & $89 \pm 5.1$ & $101 \pm 5.2$ & $85 \pm 10$ & $93 \pm 4.5$ & $99 \pm 3.3$ & $100 \pm 1.5$ \\
(mg/dL) & SG & $101 \pm 4$ & $107 \pm 6$ & $105 \pm 7$ & $104 \pm 5$ & $103 \pm 5$ & $108 \pm 2$ & $105 \pm 5$ \\
& DG & $93 \pm 3.6$ & $94 \pm 4.0$ & $89 \pm 5.2$ & $94 \pm 7.1$ & $101 \pm 6$ & $96 \pm 6.9$ & $104 \pm 7.2$
\end{tabular}


the distended group (Fig.2-3). The others biochemical values of the peritoneal fluids are presented in Table 2.

\section{DISCUSSION}

The peritoneal fluid total protein concentration increased postoperatively in the sham-operated and distended groups; however, it occurred earlier and with greater magnitude in the distended group, showing that distension has a direct influence on this variable. Interestingly, only the values obtained after three hours of distension were slightly above the standard reference value of $2.5 \mathrm{mg} / \mathrm{dL}$ (DeHeer et al. 2002). Considering that in this study horses were subjected to laparotomy in order to induce obstruction, it could be expected that these values are even lower in horses with naturally acquired simple obstructions. Therefore, our data indicate that, in cases of compression of the small colon wall due to luminal distension, the total protein concentration in peritoneal fluid increases slowly and gradually, not reaching values above the reference within the first few hours.

The peritoneal fluid total protein concentration has been one of the major indicators used to detect intestinal devitalisation (Datt \& Usenik 1975, Browlow et al. 1981, Parry et al. 1983, Ruggles et al. 1993), and detection of values above the reference range must be considered together with other variables when contemplating the need for surgery (Macoris 1995). However, it has been shown that analysis of a single value is not reliable to predict the type of lesion, the need for surgery, or to establish the prognosis (Baccarin et al. 1995, Freden et al. 1998). The present study shows that the use of a single sample of peritoneal fluid may have little value for diagnosis; however, serial evaluation was useful to distinguish the group with small colon ischemia from the group that had obstruction only, even when the values were below the reference. Considering these data, serial evaluation of peritoneal fluid total protein may be a suitable indicator for the need for surgery in horses with small colon obstruction.

Moreover, the occurrence of total protein concentrations under the standard reference value of $2.5 \mathrm{~g} / \mathrm{dL}$ even with intestinal ischemia reported here support previous studies that suggested a maximum reference value of $1.5 \mathrm{~g} / \mathrm{dL}$ (Browlow et al. 1981, Garma-Aviña 1998). Some authors consider that $2.5 \mathrm{~g} / \mathrm{dL}$ should be used, considering the difficulty in obtaining accurate values lower than this with the refractometer, which is the most widely used method (DeHeer et al. 2002). However, the high correlation between the refraction index, obtained with a portable refractometer, with the values obtained by the biuret method, employed in this study, has been recently demonstrated for total protein values between 0.6 and $2.5 \mathrm{~g} / \mathrm{dL}$ in equine peritoneal fluid (George \& O'Neill 2001). Thus, serial analysis of peritoneal fluid total protein concentration, as recommended here, may be employed even under field conditions, using a portable refractometer.

Lactate dehydrogenase (LDH) curves were similar to the TP curves. The LDH activity reached values above the reference range at $60 \mathrm{~min}$ in the distended group and at 150 min in the sham-operated group (Browlow et al. 1981, DeHeer et al. 2002). Data regarding LDH activity in perito- neal fluid of horses is limited. It is considered that an increase in LDH activity could reflect subsequent increases in lactate concentration since this enzyme catalyses the conversion of pyruvate into lactate during anaerobic glycolysis (DeHeer et al. 2002). Therefore, LDH has been used as a marker for cell damage and was found increased in the peritoneal fluid of horses subjected to abdominal surgery (Van Hoogmoed et al. 1999). The early and continuous increase in LDH activity observed in the distended group, compared with the sham-operated group, indicates serial evaluation of this enzyme may be useful for early determination of intestinal ischemia and thus the need for surgery.

Interaction among groups and across time were also observed for peritoneal fluid total nucleated cells (TNC), which increased at $180 \mathrm{~min}$ in the distended group, compared with the baseline value, and with the control group at the same times. These increases were mostly due to increases in segmented neutrophils, which had the same profile as the TNC. This data demonstrated that serial evaluation of peritoneal fluid TNC can be useful, although significant increases were observed only after three hours of distension.

No significant changes were found in the concentration of glucose and fibrinogen in the blood or peritoneal fluid samples. Peritoneal fluid glucose concentrations below 30 $\mathrm{mg} / \mathrm{dL}$ and fibrinogen concentrations above $200 \mathrm{mg} / \mathrm{dL}$ were shown to be associated with clinical cases of septic peritonitis (Van Hoogmoed et al. 1999). Significant increases in peritoneal fluid fibrinogen concentration have also been observed in experimental models of peritonitis (Faria et al. 1999, Mendes et al. 1999).

Serial sampling of peritoneal fluid did not result in any adverse effects during this experimental period, corroborating previous findings (Juzwiak et al. 1991, Mendes et al. 1999, Peiró et al. 1999), and therefore can be considered a safe technique. However, abdominocentesis should be performed with care since complications, although uncommon, have been reported and can be serious (Tulleners 1983). In sham-operated and distended groups, some blood contamination was expected due intra-operative bleeding associated with the laparotomy and enterotomy; however, such contamination does not seem to have affected other variables, since there were no significant changes in erythrocyte counts in any of the groups or across time. Peritoneal fluid contamination with up to $17 \%$ blood was considered acceptable since it did not significantly alter total protein concentration or total nucleated cells (Malark et al. 1992).

Between 60 and 120 minutes of distension, five horses from the distended group were restless and two of them demonstrated pawing. Although these signs are indicators of visceral pain and can be associated with the luminal distension, one horse without surgery (control group) also demonstrated pawing. No horse in this study showed signs of severe abdominal pain; there were no significant changes in the capillary refill time or in the heart and respiratory 
rates suggestive of abdominal pain. Comparable results were obtained with a similar distension model in the rectum, where none of the horses with rectal pressures up to pressures of up to $220 \mathrm{~mm}$ of $\mathrm{Hg}$ demonstrated signs of severe pain (Skarda \& Muir 2003). Such results corroborate with previous observations that the deterioration in the clinical status of the equine patient occurs slowly in cases of simple obstruction of the small colon (Datt \& Usenik 1975, Blue 1979, Gay et al. 1979, Dart et al. 1992, Hassel et al. 1999, Rhoads et al. 1999).

The lack of significant clinical changes and the absence of severe signs of abdominal pain in the present study are in agreement with previous clinical observations that clinical signs of an acute abdomen associated with simple obstructions of the small colon are less evident than those arising from diseases affecting other segments of the equine gastrointestinal tract. Considering that most laboratory variables evaluated in this study did not increase above the reference values, which is also in agreement with previous clinical observations (Gay et al. 1979, Hassel et al. 1999, Rhoads et al. 1999), serial evaluation of the peritoneal fluid is necessary to detect subtle changes in these variables.

\section{CONCLUSION}

Distension of the equine small colon induced progressive increases in nucleated cell counts and total protein and $\mathrm{LDH}$ concentrations in the peritoneal fluid during the first hours. Serial collection of the peritoneal fluid was considered to be safe and effective and analysis of total protein and LDH concentrations may be useful for early detection of intestinal devitalization in clinical cases of equine small colon obstruction, allowing determination of the need for surgery before intestinal perforation becomes imminent.

Acknowledgements.- Supported by grants from Fundação de Amparo à Pesquisa do Estado de São Paulo (Proc.00-2151-6), and the Coordenação de Aperfeiçoamento de Pessoal de Nível Superior do Ministério da Educação e Cultura. The authors thank Dr. Luciane Rasera, Renata Lemos Nagib Jorge and Diego Macri for technical assistance.

\section{REFERENCES}

Baccarin R.Y.A., Thomassian A., Nicoletti J.L.M., Gardolfi W. \& Hussni C.A. 1995. Alterações do líquido peritoneal em eqüinos com desconforto abdominal e suas relações com o tipo de lesão implantada e evolução após tratamento médico ou cirúrgico: análise de 74 casos. Braz. J. Vet. Res. Anim. Sci. 32:256-265.

Blue M.G. 1979. Enteroliths in horses: A retrospective study of 30 cases. Equine Vet. J. 11:76-84.

Browlow M.A., Hutchins D.R. \& Johnston K.G. 1981. Reference values for equine peritoneal fluid. Equine Vet. J 13:127-130.

Corrêa R.R., Zoppa A.L.V., Silva L.C.L.C., Fernandes W.R., Baccarin R.Y.A., Cruz R.S.F. \& Fantoni D.T. 2006. Estudo retrospectivo dos casos de enterolitíase e corpo estranho em intestino grosso de eqüinos, no período de janeiro de 1993 a janeiro de 2003. Braz. J. Vet. Res. Anim. Sci. 43:242-249.

Datt S.C. \& Usenik E.A. 1975 Intestinal obstruction in the horse physical signs and blood chemistry. Cornell Vet. 65:152-172.

Dart A.J., Snyder J.R., Pascoe J.R., Farver T.B. \& Galuppo L.D. 1992.
Abnormal conditions of the equine descending (small) colon: 102 cases (1979-1989). J. Am. Vet. Med. Assoc. 200:971-978.

DeHeer H.L., Parry B.W. \& Grindem C.B. 2002. Peritoneal fluid, p.127162. In: Cowell R.L. \& Tyler R.D. (Eds), Diagnostic Cytology and Hematology of the Horse. Mosby, St Louis.

Edwards G.B. 1997. Diseases and surgery of the small colon. Vet. Clin. North Am., Equine Pract. 13:359-375.

Faria E.P., Marques Júnior A.P. \& Alves G.E.S. 1991. Características celulares e bioquímicas do líquido peritoneal de eqüinos submetidos a peritonite experimental. Arq. Bras. Med. Vet. Zootec. 51:335-344.

Faleiros R.R., Alves G.E.S., Santos R.L., Marques Junior A.P. \& Macoris D.G. 2001. Experimental ischemia and reperfusion in equine small colon. Arq. Bras. Med. Vet. Zootec. 53:341-350.

Faleiros R.R., Macoris D.G., Alessi A.C., Saquetti C.H. \& Rasera L. 2002. Effect of intraluminal distension on microvascular perfusion in the equine small colon. Am. J. Vet. Res. 63:1292-1297.

Faleiros R.R., Macoris D.G., Alves G.E.S., Souza D.G., Teixeira M.M. \& Moore R.M. 2008. Local and remote lesions in horses subjected to small colon distension and decompression. Can. J. Vet. Res. 72:68-76.

Freden G.O., Provost P.J. \& Rand W.M. 1998 Reliability of using results of abdominal fluid analysis to determine treatment and predict lesion type and outcome for horses with colic: 218 cases (1991-1994). J. Am. Vet. Med. Assoc. 213:1012-1015.

Garma-Aviña A. 1998. Cytology of 100 samples of abdominal fluid from 100 horses with abdominal disease. Equine Vet. J. 30:435-444.

Gay C.C., Speirs V.C., Christie B.A. \& Parry B. 1979. Foreign body obstruction of the small colon in six horses. Equine Vet. J. 11:6063.

George J.W. \& O'Neill S.L. 2001. Comparison of refractometer and biuret methods for total protein measurement in body cavity fluids Vet. Clin. Pathol. 30:16-18.

Hassel D.M., Langer D.L., Snyder J.R., Drake C.M., Goodell M.L. \& Wyle A. 1999. Evaluation of enterolithiasis in equids: 900 cases (19731996). J. Am. Vet. Med. Assoc. 214:233-237.

Hassel D.M. 2002. Enterolithiasis. Clin. Tech. Equine Pract. 1:143147.

Juzwiak J.S., Ragle C.A., Brown C.M., Krehbiel J.D. \& Slocombe R.F. 1991. The effect of repeated abdominocentesis on peritoneal fluid constituents in the horse. Vet. Res. Commun. 15:177-180.

Keller S.D. \& Horney F.D. 1985. Diseases of the equine small colon. Comp. Cont. Educ. Pract. Vet. 7:s113-s120.

Macoris D.G. 1995. Importância da avaliação do líquido peritoneal no diagnóstico e prognóstico da cólica. Anais $2^{\circ}$ Ciclo Internacional de Cólica Equina, Jaboticabal, SP, p.21-23.

Malark J.A., Peyton L.C. \& Glavin M.J. 1992. Effects of blood contamination on equine peritoneal fluid analysis. J. Am. Vet. Med. Assoc. 201:1545-1548.

Mendes L.C.N., Marques L.C., Bechara G.H. \& Peiró J.R. 1999. Experimental peritonitis in horses: Peritoneal fluid composition. Arq. Bras. Med. Vet. Zootec. 51:217-221.

Parry B.W., Gay C.C. \& Anderson G.A. 1983. Assessment of the necessity for surgical intervention in cases of equine colic: A retrospective study. Equine Vet. J. 15:216-221.

Peiró J.R., Campebell R.C., Santana A.E. \& Valadão V.A.A. 1999. Clinical and laboratory evaluation of horses after intraperitoneal injection of lipopolysaccharide (LPS). J. Equine Vet. Sci. 19:187-191.

Pippi N.L. \& Lumb W.V. 1979. Objective tests of analgesic drugs in ponies. Am. J. Vet. Res. 80:1082-1086.

Rhoads W.S., Barton M.H., Parks A.H. 1999. Comparison of medical 
and surgical treatment for impaction of the small colon in horses: 84 cases (1986-1996). J. Am. Vet. Med. Assoc. 214:1042-1047.

Ruggles A.J., Freeman D.E., Acland H.M. \& FitzSimmons M. 1993. Changes in fluid composition on the serosal surface of jejunum and small colon subjected to venous strangulation obstruction in ponies. Am. J. Vet. Res. 54:333-340.

Sampaio I.B.M. 2002. Estatística Aplicada à Experimentação Animal. $2^{a}$ ed. Fundação de Ensino e Pesquisa em Medicina Veterinária e Zootecnia, Belo Horizonte. 265p.

Skarda R.T. \& Muir W.W. 2003. Comparison of electroacupuncture and butorphanol on respiratory and cardiovascular effects and rectal pain threshold after controlled rectal distension in mares. Am. J. Vet. Res. 64:137-144.

Snyder J.R. \& Spiers S.J. 1996. Abnormal conditions of the descending (small) colon, p.774-775. In: Smith B.P. (Ed.), Large Animal Internal Medicine. Mosby, St Louis.

Speirs V.C. 1997. The alimentary tract, p.261-298. In: Ibid. (Ed.), Clinical Examinations of Horses. W.B. Saunders, Philadelphia.

Tulleners E.P. 1983. Complications of abdominocentesis in the horse. J. Am. Vet. Med. Assoc. 182:232-234.

Van Hoogmoed L., Rodger L.D., Spier S.J., Gardner I.A., Yarbrough T.B. \& Snyder J.R. 1999. Evaluation of peritoneal fluid pH, glucose concentration, and lactate dehydrogenase activity for detection of septic peritonitis in horses. J. Am. Vet. Med. Assoc. 214:1032-1036.

Welles E.G. 2000. Clinical interpretation of equine leukograms, p.405410. In: Feldman B.F., Zinkal J.G. \& Jain N.C. (Eds), Schalm's Veterinary Hematology. Lippincott Williams and Wilkins, Philadelphia. 